\title{
New Prospects and Strategies for Drug Target Discovery in Neurodegenerative Disorders
}

\author{
Brian S. Hilbush, ${ }^{*}$ John H. Morrison, ${ }^{\dagger}$ Warren G. Young, ${ }^{*}$ J. Gregor Sutcliffe, ${ }^{\ddagger}$ \\ and Floyd E. Bloom* \\ *Neurome, Inc., La Jolla, California 92037; `Neurobiology of Aging Laboratories, Department of Neuroscience, \\ Mount Sinai School of Medicine, New York, New York 10029; and ${ }^{\ddagger}$ Department of Molecular Biology, \\ The Scripps Research Institute, La Jolla, California 92037
}

\begin{abstract}
Summary: The future of neurodegenerative therapeutics development depends upon effective disease modification strategies centered on carefully investigated targets. Pharmaceutical research endeavors that probe for a much deeper understanding of disease pathogenesis, and explain how adaptive or compensatory mechanisms might be engaged to delay disease onset or progression, will produce the needed breakthroughs. Below, we discuss the prospects for new targets emerging out of the study of brain disease genes and their associated pathogenic path-
\end{abstract}

ways. We describe a general experimental paradigm that we are employing across several mouse models of neurodegenerative disease to elucidate molecular determinants of selective neuronal vulnerability. We outline key elements of our target discovery program and provide examples of how we integrate genomic technologies, neuroanatomical methods, and mouse genetics in the search for neurodegenerative disease targets. Key Words: Neurodegeneration, therapeutics, genes, Alzheimer's, genomics, QTL.

\section{INTRODUCTION}

Neurodegenerative diseases confront mankind in a variety of guises and induce chronic suffering and debilitation for a significant percentage of the worldwide population. As a group, these disorders are a major burden on health care systems, with expenditures reaching nearly $\$ 84$ billion for Alzheimer's disease (AD) in the U.S. alone. ${ }^{1}$ The pharmaceutical industry faces arguably its most difficult challenge in attempting to develop therapeutics for neurodegenerative disease. The hurdles to overcome for disease prevention will not be cleared by prior research strategies relying on known, pharmacologically validated targets present in classical neurotransmitter or neuropeptide systems. With the possible exception of Parkinson's disease (PD), no logical relationship exists between any transmitter system and the circuitry affected by a neurodegenerative process. Indeed, neurons exhibit striking disease-specific vulnerabilities. What gives rise to this selective vulnerability remains a mystery, as do how and when disease progression is initiated

Address correspondence and reprint requests to Floyd E. Bloom, M.D., Neurome, Inc., 11149 North Torrey Pines Road, La Jolla, CA 92037. E-mail: fbloom@neurome.com. and the rate at which it progresses. Research aimed at identifying disease-causing alleles in rare familial forms of neurodegenerative disease has illuminated important molecules participating in pathological mechanisms but has not yielded suitable targets from a medicinal chemistry perspective. Considerable effort will be required to overcome translational blocks in drug discovery for nontypical drug targets.

The therapeutics currently approved by the Food and Drug Administration or in clinical trials attempt to address disease symptoms and are largely aimed at ameliorating cognitive or motoric decline, but not at the mechanisms underlying the actual neurodegeneration and disease progression.

This current state of affairs reflects two points of weakness. First, despite the enormous research focused on $\mathrm{AD}$ and other neurodegenerative disorders, the underlying pathophysiology is not yet understood in sufficient detail. The situation is certainly a consequence of the complex interplay of genes, environment and their myriad interactions. Second, there is not yet a clear means by which to establish efficacy in slowly progressing, lateonset disorders. Given the nature of these diseases, future therapeutics will need to be paired with tests for biomar- 
kers indicating onset of brain pathology that precedes overt clinical symptoms.

Traditional hurdles to brain disease treatment also remain: small molecule therapeutics must cross the bloodbrain barrier and locate their targets in discrete neuroanatomical locations. It is also hoped that these medications would not impair normal cognitive functioning and be tolerated over long periods of time. Financial barriers must also be scaled because these therapies will entail slow, costly development and may involve novel delivery mechanisms. Finally, the approved medications will likely be expensive, and introduction into clinical practices may be slow. The extraordinary societal costs anticipated for the future in the absence of effective treatments has provided a dramatic sense of urgency for development of effective interventions.

\section{NEURODEGENERATIVE DISEASE GENE PRODUCTS AND THERAPEUTIC TARGETS}

Knowledge of the neuropathological and molecular features of familial forms of neurodegenerative diseases has provided a rational foundation for exploring new therapeutic targets. Genetic and neuroanatomical approaches that generate these molecular clues remain the front line of attack for target discovery, in large part due to the lack of understanding of the pathophysiology of most neurodegenerative diseases. Indeed, nearly 20 years have passed since the amyloid $\beta$ peptide $(\mathrm{A} \beta)$ was discovered as the protein constituent of amyloid plaques. ${ }^{2}$ However, little consensus exists as to what constitutes the toxic $\mathrm{A} \beta$ species, how or where (or if?) the aberrant peptide initiates a toxic disease process, or what serves as its primary target. ${ }^{3}$ Candidates for mechanism-based targets in neurodegenerative disorders have arisen chiefly out of the initial identification of disease genes through genetic linkage and mapping approaches. In $\mathrm{AD}$, the subsequent identification of rare disease-causing mutations in the genes encoding the amyloid precursor protein $(\mathrm{APP})^{4}$ and the presenilins (PS-1 and PS-2), ${ }^{5,6}$ each of which leads to overproduction of the more amyloidogenic form of $\mathrm{A} \beta\left(\mathrm{A} \beta_{1-42}\right),{ }^{7}$ immediately suggested new routes to AD therapy based on modification of APP metabolism. ${ }^{8}$ Since those discoveries, the pathogenic molecular characteristics and disease genes underlying several familial forms of progressive neurodegenerative disorders have been elucidated. Here, we classify the diseases into major groupings based on unifying neuropathological processes and molecular features (Table 1). This classification scheme reveals therapeutic target similarities and aligns disorders with aberrant protein aggregation, those defined primarily by defects in DNA damage repair, and disorders whose disease gene products are targeted to the mitochondrion. Similar classification schemes have been proposed by others. ${ }^{9}$

\section{PROTEIN AGGREGATION DISORDERS}

The defining pathological process across many common neurodegenerative disorders is the generation of toxic proteins and their accumulation into aggregates in the form of extracellular plaques, intracellular neurofibrillary tangles and cytoplasmic or intranuclear inclusions. ${ }^{10} \mathrm{~A}$ remarkable convergence of evidence from neuropathologic and molecular genetic investigations has demonstrated that the disease gene products are often intimately tied to aggregate formation, typically as the source of the protein. $\mathrm{A} \beta_{1-42}$ accumulates in senile plaques seen in all forms of AD. Filamentous tau inclusions are a common feature in sporadic disorders and frontotemporal dementias. ${ }^{11,12}$ In prion diseases, the mutant protein, termed $\operatorname{PrP}^{\mathrm{sc}}$, fibrillizes and forms numerous amyloid deposits. ${ }^{13}$ The protein $\alpha$-synuclein is found in inclusions called Lewy bodies in $\mathrm{PD}^{14}$ and mutant SOD1 is found in intraneuronal inclusions in some forms of familial amyotrophic lateral sclerosis (ALS) ${ }^{15}$ For polyglutamine expansion disorders, Huntington's disease is the prototypical example, and mutant huntingtin protein is found sequestered in cytoplasmic and nuclear inclusions within affected cortical pyramidal neurons in human diseased brain. ${ }^{16,17}$ Both protective and toxic properties have been ascribed to the various deposits described above and the nature of the toxic protein species is a matter of contentious debate for many of the diseases.

For the majority of disorders in the aggregation class, the therapeutic target opportunities afforded by the activities of the disease gene products themselves appear to be limited. At present, the cellular functions and activities for the majority of these proteins are unknown. The proposed molecular mechanisms underlying the aggregation diseases now largely center on the toxic gain-offunction properties of the pathogenic proteins. Thus, it is uncertain how a therapeutic benefit would derive from targeting the mutant proteins' normal activity. In some cases, partial loss of function of the normal activity of the gene product may be a factor in selective neuronal vulnerability. ${ }^{18,19}$

The relationship between neurodegenerative disease genes and the appearance of aberrant protein deposits has focused considerable attention on molecular pathways involved in protein clearance and on novel therapeutic strategies to prevent toxic protein generation and aggregate formation. Delineation of the APP proteolytic processing pathway was crucial in formulating most of the current strategies to reduce $\mathrm{A} \beta_{1-42}$ production. APP is a transmembrane protein that is normally metabolized along two alternative routes, the $\alpha$-secretase and $\beta$-secretase pathways. APP processing down the $\alpha$-secretase pathway precludes $\mathrm{A} \beta$ formation because the $\alpha$-secretase enzyme cleaves in the middle of the amyloid $\beta$ region. 
TABLE 1. Drug Target Characteristics of Neurodegenerative Disease Gene Products

\begin{tabular}{|c|c|c|c|}
\hline Familial Disease & Disease Gene Product & Cellular Function & Role as Target \\
\hline \multicolumn{4}{|c|}{ Disorders with Aberrant Protein Aggregation } \\
\hline \multirow[t]{2}{*}{ Alzheimer's disease } & Presenilin- 1 and 2 & $\begin{array}{l}\text { Proposed aspartyl proteases; } \\
\text { component of } \gamma \text {-secretase } \\
\text { complex }\end{array}$ & $\begin{array}{l}\text { Small molecule targets-protease } \\
\text { inhibitors }\end{array}$ \\
\hline & $\begin{array}{l}\text { Amyloid precursor protein } \\
(\mathrm{A} \beta)\end{array}$ & Unknown & $\begin{array}{l}\text { Antibody target }\left(\mathrm{A} \beta_{1-42}\right) \text {; target } \\
\text { for aggregation inhibitors }\end{array}$ \\
\hline $\begin{array}{l}\text { Familial British/Danish } \\
\text { dementia }\end{array}$ & Bri2 & Unknown & \\
\hline $\begin{array}{l}\text { Frontotemporal dementia } \\
\text { (FTDP-17) }\end{array}$ & tau & $\begin{array}{l}\text { Microtubule assembly and } \\
\text { stability }\end{array}$ & \\
\hline Prion diseases & $\mathrm{PrP}^{\mathrm{ac}}$ & Unknown & $\begin{array}{l}\text { Small molecule target-pathogenic } \\
\text { conformation inhibitors }\end{array}$ \\
\hline $\begin{array}{l}\text { Familial encephalopathy } \\
\text { with neuroserpin } \\
\text { inclusion bodies } \\
\text { (FENIB) }\end{array}$ & Neuroserpin & Serine protease inhibitor & \\
\hline Parkinson's disease* & $\alpha$-Synuclein & $\begin{array}{l}\text { Unknown; roles in } \\
\text { presynaptic function }\end{array}$ & \\
\hline Huntington's disease & Huntingtin & $\begin{array}{l}\text { Unknown; putative roles in } \\
\text { vesicle recycling, } \\
\text { transcription }\end{array}$ & \\
\hline $\begin{array}{l}\text { Amyotrophic lateral } \\
\text { sclerosis }\end{array}$ & $\mathrm{Cu}, \mathrm{Zn}$ SOD1 & Superoxide metabolism & \\
\hline $\begin{array}{l}\text { Hereditary spastic } \\
\text { paraplegia-SPG4 }\end{array}$ & Spastin & $\begin{array}{l}\text { Role in microtubule } \\
\text { dynamics }\end{array}$ & \\
\hline $\begin{array}{l}\text { Dentatorubropallidoluysian } \\
\text { atrophy (DRPLA) }\end{array}$ & DRPLA (atrophin-1) & Unknown & \\
\hline $\begin{array}{l}\text { Spinobulbar muscular } \\
\text { atrophy }\end{array}$ & Androgen receptor & $\begin{array}{l}\text { Ligand-activated } \\
\text { transcription factor }\end{array}$ & $\begin{array}{l}\text { Small molecule target-ligand } \\
\text { antagonists }\end{array}$ \\
\hline $\begin{array}{l}\text { Spinocerebellar ataxias } 1, \\
2,3,7,10\end{array}$ & Ataxins- $1,-2,-3,-7,-10$ & Roles in gene regulation & \\
\hline SCA6 & CACNA1A & $\mathrm{Ca}^{2+}$ channel $\alpha$ 1a subunit & \\
\hline SCA14 & Protein kinase $\mathrm{C} \gamma$ & Protein kinase $\mathrm{C} \gamma$ & \\
\hline SCA17 & TATA binding protein & Transcriptional regulator & \\
\hline Lafora disease & Laforin & Dual specificity phosphatase & \\
\hline & Malin & E3 ubiquitin ligase & \\
\hline $\begin{array}{l}\text { Fragile } \mathrm{X} \text {-associated } \\
\text { tremor/ataxia } \\
\text { syndrome (FXTAS) }\end{array}$ & FMR1 & RNA binding protein & \\
\hline \multicolumn{4}{|c|}{ Disorders with Mitochondrion-Targeted Disease Gene Products } \\
\hline Wilson's disease ${ }^{\dagger}$ & ATP7B & $\begin{array}{l}\text { P-type (copper transporting) } \\
\text { ATPase }\end{array}$ & None; decoppering therapy \\
\hline Fredereich's ataxia & Frataxin & $\begin{array}{l}\text { Iron homcostasis; heme } \\
\text { synthesis }\end{array}$ & \\
\hline $\begin{array}{l}\text { Mohr-Tranebjaerg } \\
\text { syndrome }\end{array}$ & $\begin{array}{l}\text { Deafness/dystonia } \\
\text { protein-1 (TIMM8A) }\end{array}$ & Unknown & \\
\hline Parkinson's disease & Pink1 & Putative protein kinase & \\
\hline $\begin{array}{l}\text { Hereditary spastic } \\
\text { paraplegia SPG7 }\end{array}$ & Paraplegin & $\begin{array}{l}\text { Putative ATP-dependent } \\
\text { protease }\end{array}$ & \\
\hline $\begin{array}{l}\text { Hereditary spastic } \\
\text { paraplegia SPG13 }\end{array}$ & HSP60 & $\begin{array}{l}\text { Mitochondrial import } \\
\text { chaperonin }\end{array}$ & \\
\hline Motor neuron disease & Cytochrome $c$ oxidase 1 & Electron transport & \\
\hline LHON & $\begin{array}{l}\text { mitochondrial complex I } \\
\text { subunits }\end{array}$ & $\begin{array}{l}\text { Mitochondrial energy } \\
\text { metabolism }\end{array}$ & \\
\hline
\end{tabular}


TABLE 1. Continued

\begin{tabular}{|c|c|c|c|}
\hline Familial Disease & Disease Gene Product & Cellular Function & Role as Target \\
\hline \multicolumn{4}{|c|}{ Disorders with Defects in DNA Damage Repair } \\
\hline Ataxia telangiectasia & ATM & Protein kinase & $\begin{array}{l}\text { Small molecule target-kinase } \\
\text { activators }\end{array}$ \\
\hline $\begin{array}{l}\text { Ataxia telangiectasia-like } \\
\text { disease }\end{array}$ & MRE11 & $\begin{array}{l}\text { Component of DNA } \\
\text { double-stranded break } \\
\text { sensor complex }\end{array}$ & \\
\hline $\begin{array}{l}\text { Nijmegen breakage } \\
\text { syndrome }\end{array}$ & Nibrin & $\begin{array}{l}\text { Component of DNA } \\
\text { double-stranded break } \\
\text { sensor complex }\end{array}$ & \\
\hline $\begin{array}{l}\text { Spinocerebellar ataxia } \\
\text { with axonal neuropa- } \\
\text { thy-1 (SCAN1) }\end{array}$ & TDP1 & Tyrosyl phosphodiesterase & \\
\hline $\begin{array}{l}\text { Ataxia with oculomotor } \\
\text { apraxia } 1\end{array}$ & Aprataxin & $\begin{array}{l}\text { Component of DNA repair } \\
\text { complex for } \\
\text { single-stranded breaks }\end{array}$ & \\
\hline $\begin{array}{l}\text { Ataxia with oculomotor } \\
\text { apraxia } 2\end{array}$ & Senataxin & Putative role in DNA repair & \\
\hline
\end{tabular}

Notes: Lysosomal storage disorders (not listed above) form a fourth class of neurodegenerative diseases that contains a large collection of over 48 distinct types resulting from defects in lysosomal membrane transporters and hydrolases; these are largely neurodevelopmental disorders of childhood. *Familial PD is caused by several additional genes, including UCHL1, LRRK2, DJ1, and Parkin. Lewy body pathology has not been definitively associated with any of these familial forms. ${ }^{\dagger}$ Wilson's disease gene product, ATP7B, is found in other subcellular compartments in addition to the mitochondrion. ${ }^{\star}$ Mutant SETX alleles were identified as the cause of a juvenile form of ALS.67

The released APP C-terminal fragment is further processed by $\gamma$-secretase to release a small fragment known as p3. Presumptively pathological cleavage of APP by the sequential activities of the $\beta$ - and $\gamma$-secretases leads directly to amyloidogenic $A \beta$ fragment formation. After $\beta$-secretase digestion of APP, multiple $\gamma$-secretase cleavage sites are present in the C-terminal fragment and allow for the production of both $\mathrm{A} \beta_{1-40}$ and pathogenic $\mathrm{A} \beta_{1-42}$. Mutations in PS- 1 and PS-2 primarily alter the specific APP C-terminal cleavage site of the $\gamma$-secretase complex, favoring production of $\mathrm{A} \beta_{1-42}{ }^{7}$ Thus, a set of therapeutic strategies emerged based on newly discovered proteases as targets: stimulation of $\alpha$-secretase, inhibition of $\beta$-secretase, and inhibition of the $\gamma$-secretase complex. ${ }^{8,9}$ The ability of a subclass of muscarinic receptors to stimulate $\alpha$-secretase activity ${ }^{20}$ led to a clinical trial for a M1 muscarinic agonist. ${ }^{21}$ Major efforts have been underway at pharmaceutical companies for over a decade to evaluate the effects on $\gamma$-secretase inhibitors on $\mathrm{AD}$ progression. ${ }^{8}$ More recently, the molecular cloning of $\beta$-secretase, ${ }^{22}$ known as $\beta$-site APP-cleavage enzyme 1 (BACE1), led to the development of pharmacological inhibitors for the enzyme. ${ }^{23,24}$ Although drug development efforts in AD aimed at APP metabolic pathway targets appear promising, the current set of mechanistic targets has potential drawbacks due in part to lack of substrate specificity. For example, APP would be but one of many substrates affected by $\gamma$-secretase inhibition, and release of the intracellular domain of Notch is dependent on the activity of this enzyme. ${ }^{25}$

The observations in transgenic mice that elevated levels of $\mathrm{A} \beta_{1-42}$, caused by overexpression of human mu- tant APP, lead to neuropathological and behavioral changes resembling human $\mathrm{AD},{ }^{26}$ and that blockade of $\mathrm{A} \beta_{1-42}$ production completely abolished $\mathrm{AD}$-like pathology $^{27}$ elevated the $\mathrm{A} \beta_{1-42}$ peptide as a prime therapeutic target. Multiple antiamyloid therapies based on removal or destruction of $\mathrm{A} \beta_{1-42}$ have been identified and demonstrated convincingly in vivo and in culture systems. These include the use of immunotherapeutic strategies to provoke $\mathrm{A} \beta_{1-42}$ clearance from the brain, ${ }^{28}$ the control of $\mathrm{A} \beta$ degradation by enhancing neprilysin activity, ${ }^{29,30}$ and the utilization of $\mathrm{A} \beta$ aggregation inhibitors to block peptide oligomerization. ${ }^{31}$ Despite these landmark advances, the effectiveness of these disease-modifying therapies has yet to be demonstrated in humans. The success and general applicability of any one of these strategies in AD would likely have a significant impact on therapeutic approaches toward the other aggregation disorders.

A variety of reports have established that protein misfolding plays a role in the pathogenic process for several of the polyglutamine expansion disorders, including those causing spinocerebellar ataxias. ${ }^{32}$ Moreover, genetic suppressor screens in Drosophila have revealed potent inhibitors of polyglutamine protein toxicity. ${ }^{33,34}$ Related experiments that examined the effects of overexpression of specific molecular chaperones in both fly and mouse models of neurodegenerative disorders confirmed the ability of Hsp70/40 chaperones to reduce $\alpha$-synuclein and polyglutamine-driven neurotoxicity and to suppress aggregate formation in some cases. ${ }^{35,36} \mathrm{An}$ antiaggregation strategy of a different sort was described in a mouse model of spinobulbar muscular atrophy 
(SBMA). ${ }^{37}$ The genetic defect in SBMA is a CAG repeat expansion located within the coding region of the androgen receptor gene. ${ }^{38}$ Testosterone is the natural ligand for the androgen receptor and retains binding affinity to the mutant receptor forms. In transgenic male mice, lowering of serum testosterone levels prevented nuclear translocation and aggregate formation normally seen with the mutant receptor and even caused a reversal of the neuromuscular phenotype. ${ }^{37}$ These examples, along with antiamyloid strategies in $\mathrm{AD}$, suggest that the toxic proteins themselves may be the most suitable molecular targets for intervention. The SMBA example establishes that ligands can induce pathogenic structures and antagonists could conceivably be developed to interfere with the toxic properties. The early success of genetic modifier screens in flies and mice to identify neuroprotective genes in ataxia indicates that similar investigations may be productive with other neurodegenerative disorders.

\section{DISORDERS WITH MITOCHONDRION- TARGETED DISEASE GENE PRODUCTS}

Mitochondrial dysfunction is a frequent cause of clinical syndromes due to mutated genes in nuclear and mitochondrial DNA. ${ }^{39}$ Disease-causing mutations are found in all 14 genes ( 7 nuclear and 7 mitochondrial) that encode subunits of the so-called "minimal enzyme" of mitochondrial complex I, which are presumed to be essential for catalyzing electron transfer from reduced nicotinamide adenine dinucleotide to ubiquinone. In neurodegenerative disease, oxidative stress is a prominent pathological feature and many studies have demonstrated that increased production of reactive oxygen species promotes neurodegeneration. MPTP, the dopaminergic neurotoxin widely used to model PD in rodents and primates, exerts its effects through complex I damage and reactive oxygen species formation. ${ }^{40}$ The disorders listed in Table 1 with a clearly unequivocal mitochondrial association help to establish the importance of mitochondrial dysfunction in neurodegenerative processes, although the precise mechanistic relationship between the two is unclear.

Prospects for therapeutic intervention in this group of disorders appear limited at present, with the exception of PD and Wilson's disease. Mitochondrial complex I is impaired in Leber hereditary optic neuropathy (LHON) ${ }^{41,42}$ Although none of the defective complex I subunits commonly found mutated in LHON or other complex I syndromes appear poised as drug targets, a recent study suggests that an inhibitor of $\mathrm{Na}^{+} / \mathrm{Ca}^{+}$exchange can reverse changes in cytosolic $\mathrm{Ca}^{2+}$ concentrations, ATP synthesis and mitochondrial membrane potential due to complex I deficiency. ${ }^{43}$ The likelihood that oxidative stress plays a central role in the pathogenesis of these disorders has prompted investigation into the use of antioxidants such as coenzyme Q10 and vitamin E. ${ }^{43 a}$ Data from a clinical trial for patients with Friedriech's ataxia suggested partial improvement of some clinical parameters with a combined treatment regimen. ${ }^{44}$ The immediate and downstream consequences of increased oxidative stress and lowered energy production in vulnerable neurons will necessitate a continued focus on effective therapeutic avenues to combat mitochondrial dysfunction.

\section{TARGETS IN DNA DAMAGE REPAIR}

The growing list of neurodegenerative disorders due to defects in DNA damage repair proteins sheds light on the exquisite sensitivity of certain populations of neurons to DNA strand breaks. As reviewed recently, ${ }^{45}$ defects in double-stranded break repair mechanisms appear to affect both neural and non-neural systems, whereas singlestrand DNA break repair defects are seemingly confined to neurons. It is especially puzzling that nonproliferating cells would be the preferential site of toxic insult from these defects. One intriguing aspect of these disorders is that they might result from a lowered threshold in the cell's ability to handle DNA damage due to oxidative stress. Among the disease gene products in this group, ATM and tyrosyl phosphodiesterase are in enzyme classes that currently could be targeted by small molecule drugs. ${ }^{46}$ Very little is yet known as to why DNA strand breaks cause neurodegenerative disease. One suggestion is that the strand breaks or the DNA-protein adducts formed interfere with transcription and somehow jeopardize neuronal function or integrity.

An assessment of the disease gene products for neurodegenerative diseases provides several reasons as to why these molecules are seen as both excellent and poor drug targets. At least some of the toxic disease proteins appear to be suitable targets for destruction, clearance, or modification by pharmaceutical compounds or antibodies. For most of the rare, recessive forms of familial disease, the identified disease proteins fall into functional classes that continue to remain outside of the expertise of drug development. In addition, many of the disease gene products encode mitochondrial components that essentially need to be replaced, as in the lysosomal storage disorders. Compared with $\mathrm{G}$ protein-coupled receptors and other protein classes successfully targeted by current compound libraries, the mechanistic targets arising from neurodegenerative diseases appear poised to require therapeutics aimed at completely new types of molecules. 
A. Experimental Paradigm

Disease-specific selective vuinerability

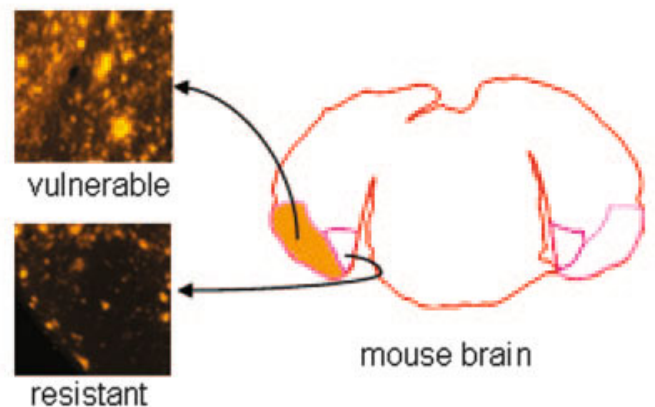

resistant

Molecular basis of selective vulnerability $\downarrow$
Mechanistic targets
Disease-modifying strategies
B. Target Discovery Approach

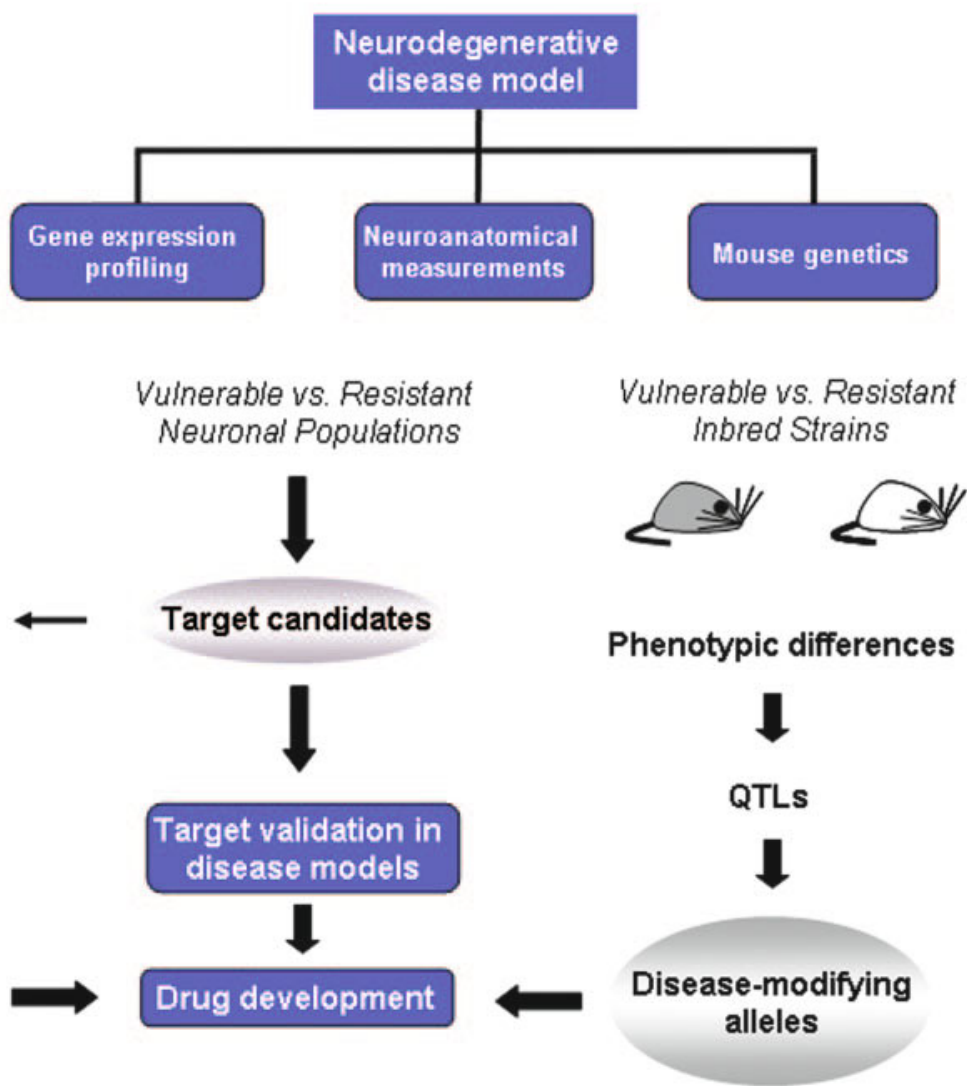

FIG. 1. Neurome's drug target discovery approach. A: An example of the experimental paradigm employed to study disease-specific selective vulnerability. Amyloid plaque staining is shown in regions of the lateral (orange shading) and medial entorhinal cortices from an AD transgenic mouse model. B: Technology platforms used at Neurome, Inc. to analyze disease vulnerability and resistance in neuronal populations and mouse inbred strains. Experimental data provide candidate therapeutic targets and disease-modifying alleles that can be further assessed and validated with studies in animal disease models and in vitro assays. The research pipeline is designed to evaluate multiple disease models across all platforms in parallel.

\section{RESEARCH STRATEGIES FOR TARGET DISCOVERY}

The introduction of molecular biology and genomics technologies, robotic instrumentation, and computational resources combined to usher in a new era of pharmaceutical discovery research in which plausible targets could be discerned from genetic analyses and biological data. Target-based drug discovery has come to virtually eclipse physiology-based (but not necessarily pathophysiology-based) approaches toward therapeutic development across the medical spectrum. This paradigm shift is here to stay, and for several good reasons. The oldfashioned procedures were low throughput, and the practitioners tended to disregard disease mechanisms to focus on symptomatic treatments. Modern target-based methods are far more amenable to high-throughput assays, and their uses facilitate rational drug discovery pro- grams. Detractors point to a coincident decline in the industries' productivity (i.e., introduction of new chemical entities and biologicals) beginning in the early 1990s with the installation of target-based discovery. However, it is readily apparent that traditional medicinal chemistry approaches have been ill equipped to deal with the vast array of genomics-derived targets falling outside of typical druggable protein classes, particularly for neurodegenerative disease (see Table 1). It is probable that future neurodegenerative therapies will be based upon novel targets where the risk of failure for developing lead compounds will be significantly higher than for those based on well-known and previously validated targets. Thus, the goal of any neuroscience discovery research program will be to provide the highest degree of biological validation possible, at the earliest feasible point in the discovery phase, to allow for selection of the best disease-modifying targets for drug development. 


\section{DISEASE-SPECIFIC SELECTIVE VULNERABILITY}

Here we describe major elements of Neurome's approach to neurodegenerative diseases and provide examples of how our technologies are employed for drug target identification. Our main discovery framework is based on exploring disease-specific selective vulnerability of neurons in mouse models of neurodegenerative disorders. The striking susceptibility of discrete neuronal populations, often in close physical proximity to resistant neurons of the same class [e.g., pyramidal neurons in affected and unaffected AD model mice (FIG. 1A)] affords tremendous opportunities to understand both pathogenic and protective mechanisms. ${ }^{47-49}$ Recent work in our laboratories on the PDAPP mouse model of $\mathrm{AD}$ illustrates an experimentally tractable example involving pyramidal neurons in the entorhinal cortex. ${ }^{50}$ Deposition of diffuse $\mathrm{A} \beta$ was quantitated throughout the entorhinal cortex of 15- to 22-month-old mice. In the lateral entorhinal cortex, the $\mathrm{A} \beta$ load achieved a maximum of $16.4 \%$, whereas loads in the medial portion remained below $2.3 \%$. This finding demonstrated a circuit-specific accumulation of $\mathrm{A} \beta$ that preferentially involves the lateral perforant path, reflected by high levels in the lateral entorhinal cortex and its terminal zone, the outer molecular layer of the hippocampus.

Our hypothesis is that the molecular clues that are sought to understand a particular neurodegenerative disease process will be discovered by identifying differences between the two populations. Likewise, we hypothesize that biological processes conferring protection from pathology are also poised to be revealed by molecular, cellular, and neuroanatomical comparisons of susceptible and resistant neurons. This approach differs significantly from prior attempts to evaluate molecular changes in neuronal subtypes from $\mathrm{AD}$ patients compared with controls. ${ }^{51}$ In human studies, genetic and environmental factors complicate interpretation in such two-way comparisons and the quality of postmortem tissue is difficult to ascertain and control. In addition, the degree of biological insight from such analyses is necessarily restricted due to sampling at terminal stages of the disease.

In one prong of our attack, we initiate genome-scale RNA profiling using TOGA (Total Gene Expression Analysis) technology to survey and compare all expressed transcripts between vulnerable and resistant populations in mouse disease models (Fig. 1B). These baseline studies are designed to examine expression changes occurring pre- and post-disease initiation and during progression, as well as near end-stage pathology. The TOGA platform rapidly identifies known, differentially expressed RNAs and provides a convenient means with which to sequence and identify novel cDNAs via corre-
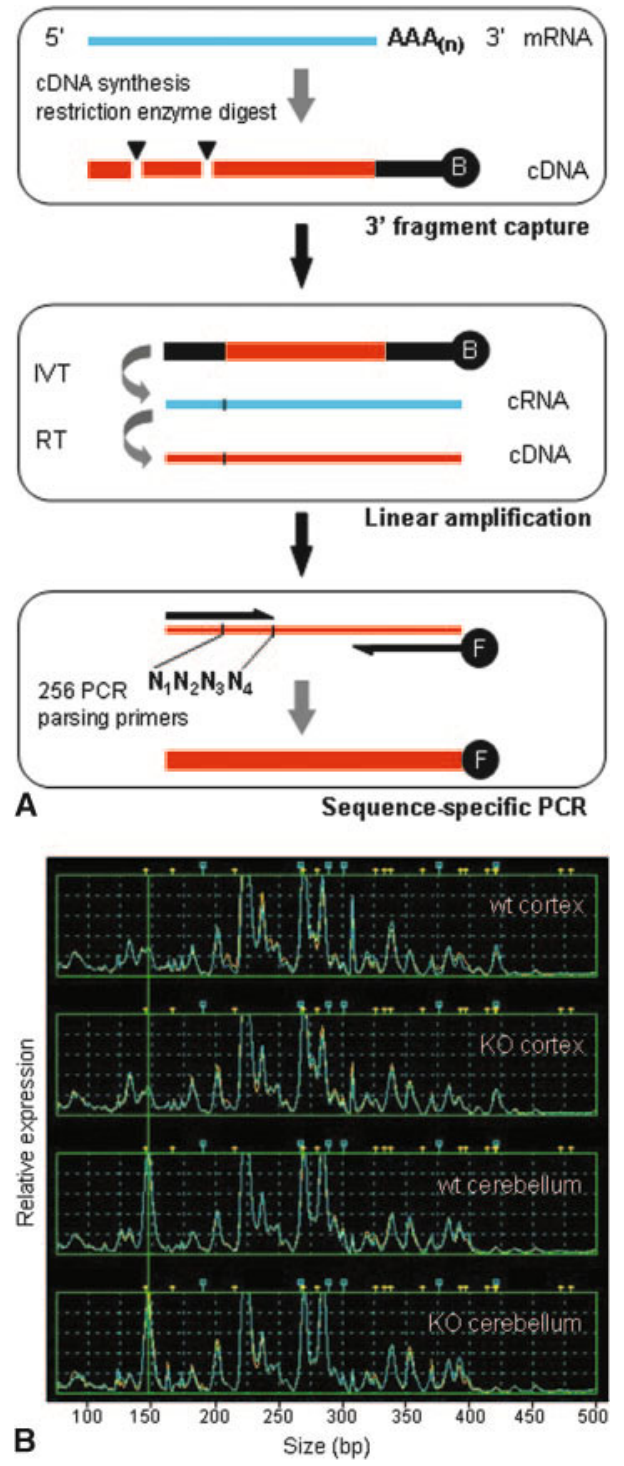

FIG. 2. A: The TOGA method. RNA from a biological sample serves as template for CDNA synthesis initiated with a biotinylated anchor primer; the cDNA is subjected to enzymatic digest by a restriction endonuclease with four-base recognition specificity (e.g., Mspl CCGG) followed by fragment capture on streptavidincoated beads (top box). In the next steps, in vitro transcription (IVT) and reverse transcription (RT) reactions (middle box) are employed for linear amplification and production of templates for PCR, respectively. PCR is performed to systematically parse the entire set of expressed RNAs and generate sequence-specific subpools for analysis (bottom box), using an array of 256 distinct $5^{\prime}$ primers whose $3^{\prime}$ termini cover all sequence possibilities across the four bases (labeled N1N2N3N4) adjacent to the restriction digest site. Fluorescently labeled PCR products are analyzed by capillary electrophoresis to measure DNA fragment size and fluorescent intensity. B: TOGA gene expression profiles. RNA samples from cerebral cortex and cerebellum of wild-type (wt) and ATM knockout mice (KO) were analyzed by TOGA, and data are shown for one of the 256 PCRs comprising the data set. Gene expression levels are indicated along the $y$-axis (relative fluorescence units) and size of PCR fragments are plotted along the $x$-axis in base pairs. Peaks represent individual mRNAs and are assigned a unique digital address based on sequence characteristics. ${ }^{53}$ The addressing feature allows a database to be established for all detected RNAs and enables prediction of corresponding gene sequences contained in genomic databases. 


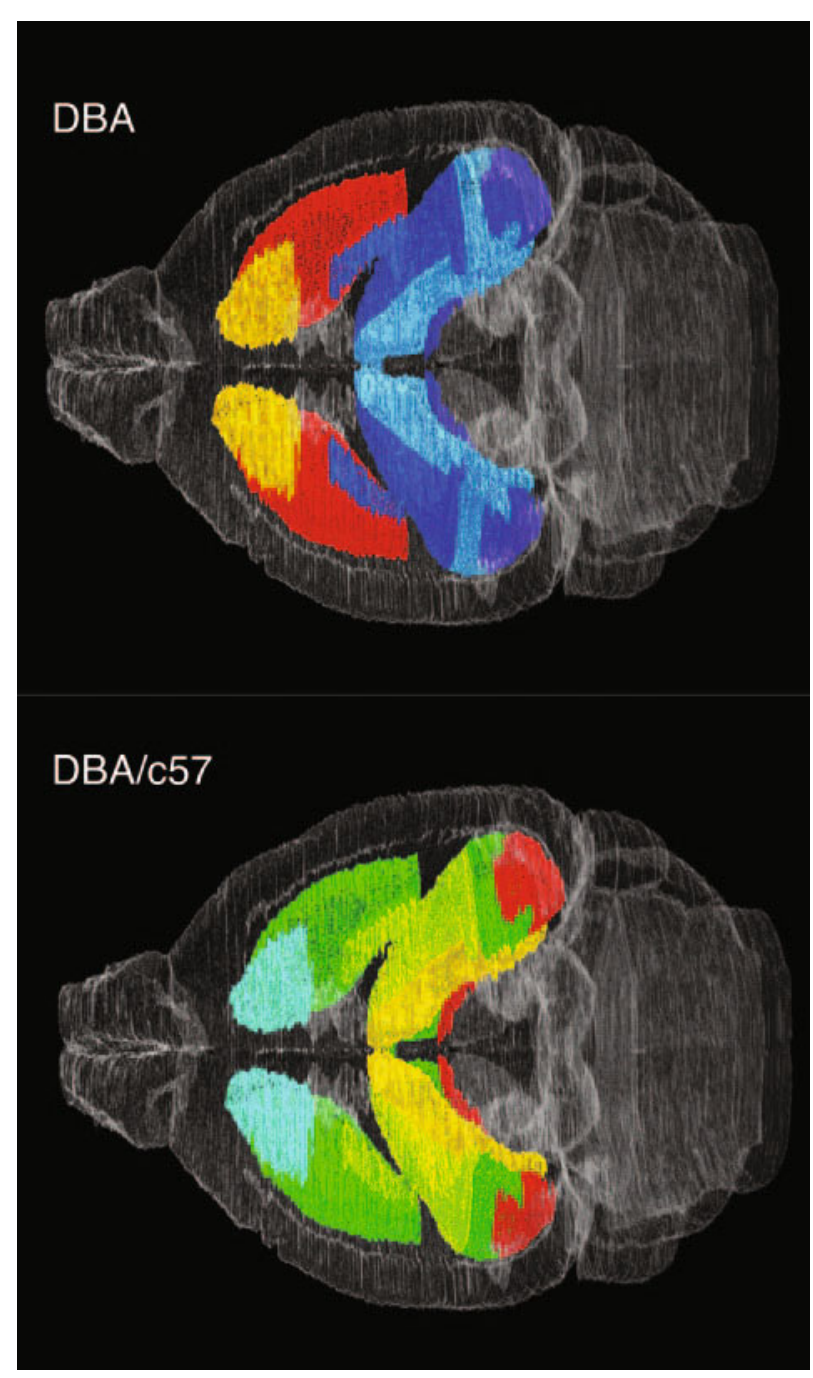

FIG. 3. Three-dimensional visualization of gene expression data in a virtual mouse brain atlas. Quantitative results from in situ hybridization analysis of preproenkephalin mRNA expression in two different mouse strains (DBA/2J and C57BL/6) displayed within the basal ganglia and hippocampus of a digital brain atlas. The top panel shows the expression levels from a DBA/2J mouse brain, and the bottom panel shows the ratio of expression for DBA/C57. Expression levels are indicated by pseudocolor representation, with low represented in blue and high in red shades on a continuous color scale. Nissl-stained reference brains were used to generate the atlas in all three orthogonal planes. The sagittal and horizontal planes are virtual sections dynamically reconstructed from the original coronal sections.

sponding PCR products. ${ }^{52,53}$ An outline of the TOGA method and an example of expression profiles generated in cerebral cortex and cerebellum from wild-type and ATM knockout mice are shown in Fig. 2, A and B. Neurome's TOGA experiment database can be queried to provide additional information regarding any gene's transcriptional regulation or localized expression across many different cell and tissue types. Identified expression differences can be further explored by in situ hybridization in multiple, related disease models and across a series of inbred mouse strains with standardized pro-

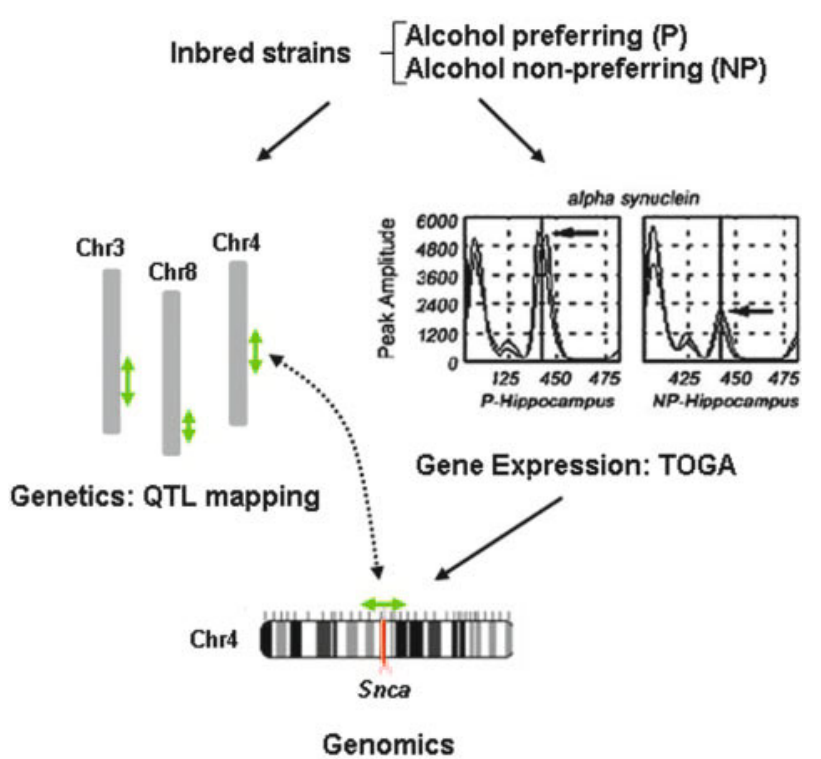

FIG. 4. QTL discovery. The combined use of inbred strains, QTL mapping, and gene expression analysis for discovery of QTL genes is depicted in the diagram. Phenotypic trait data were used to map loci underlying alcohol preference in inbred rat strains. Gene expression analysis of various brain regions identified differentially expressed transcripts in the P and NP strains. The mRNA for $\alpha$-synuclein was expressed at higher levels in $P$ hippocampus and the chromosomal position of the gene corresponded to the peak of the QTL identified on chromosome 4.

tocols (Fig. 3). These data are then assessed in the context of Neurome's digital mouse brain atlas, BrainArchive, and can be processed and displayed in two- and three-dimensional reconstructions to reveal associations with known transmitter systems, circuits or other neuroanatomical features. Genes that are differentially expressed in vulnerable and resistant neurons, show altered expression during disease initiation or progression, and whose protein product might be functionally important in a disease cascade would represent first tier candidates as targets for further assessment. The target candidates, individually or collectively, will yield important insights into the molecular basis of selective vulnerability. Integration of data accumulated on sets of genes across multiple technology platforms may suggest new pathogenic mechanisms. For chosen candidate targets, validation studies performed in the relevant disease model will provide proof of principle in vivo and justify initiation of drug development activities (Fig 1A).

\section{Genetic Modifiers and Quantitative Trait Loci}

Neurome's target discovery operation employs mouse genetics to further explore selective neuronal vulnerability and to identify genes that modify disease susceptibility. Genetic modifiers, either protective or risk conferring, are known to exist that impact disease severity and age of onset for several human neurodegenerative disorders, including PD, ALS, AD, and Huntington's dis- 
ease ${ }^{54-59}$ In humans, genetic analysis of complex traits and modifiers remains difficult, due principally to the varying contributions of genetic heterogeneity, stochastic effects, and environment on trait variation. As a case in point, traditional genetic linkage analysis to identify disease age of onset modifiers in human AD populations would have missed the apoE4 locus. ${ }^{60}$ Many of these problems are easily overcome by use of inbred mice, where the disease phenotypes depend strongly on genetic background and the environment can be controlled in a laboratory setting. The use of carefully designed crosses can minimize genetic heterogeneity and identify new combinations of alleles that modify disease in the context of a healthy organism. Large repertoires of allelic combinations already exist in recombinant inbred strains, and these can be exploited to identify modifiers in several ways. For example, mutant strains or transgenic mice carrying human disease transgenes can be crossed onto the unique and well-defined genetic backgrounds of recombinant inbred strains for phenotype analyses and mapping studies.

Determination of significant phenotypic differences between two strains allows for subsequent mapping of quantitative trait loci (QTL) harboring risk-conferring or protective alleles by several strategies. In rodents, over 2300 QTLs have been mapped; several dozen of these relate to neurological and neurobehavioral phenotypes relevant to human brain diseases. This genetic approach is conceptually related to the experimental paradigm comparing vulnerable and resistant neuronal populations as outlined above. With the genetic tools, comparisons are made between strains that differ in susceptibility to a neurodegenerative disease process. Genetic backgrounds are thus tested in a pair-wise manner to identify alleles that influence the physiology of the vulnerable and resistant neuronal populations.

\section{Combined genomic approaches to QTL gene discovery}

We have developed gene expression-based methodologies to detect QTL genes that depend upon correlation of gene expression data with phenotypic trait data and mapping results (Fig. 4). Similar combined approaches have been suggested and performed by others. ${ }^{61,62}$ Determination of the gene underlying a particular QTL is often a tedious and time-consuming step in trait analysis. Current mapping techniques provide genetic resolution down to a range near $3 \mathrm{cM}$, an interval that spans 50-60 genes (assuming random distribution of 30,000 genes across a $1500 \mathrm{cM}$ genome). Because the underlying genetic differences we seek arise from changes in either coding sequence or gene regulatory regions, gene expression measurements offer a way to rapidly screen candidates within a given locus.
An example of one approach whereby gene expression profiling was combined with behavioral testing to identify quantitative trait genes underlying alcohol-seeking behavior is outlined in Figure 4. In this study, selectively inbred rat strains [alcohol-preferring $(\mathrm{P})$ and non-preferring (NP)] were analyzed that display significant differences in alcoholism-related traits, such as in their consumption and preference for alcohol. In previous genetic mapping studies, multiple QTLs were identified and positioned on chromosomes 3,4 , and $8 .{ }^{63,64}$ These loci each span several $\mathrm{cM}$ and harbor a large number of candidate genes. TOGA profiling of several brain regions revealed genes whose expression differed between the strains. ${ }^{65}$ The TOGA expression analysis revealed nearly 20,000 expressed mRNAs. Among these, 28 mRNAs displayed differential expression when samples from $\mathrm{P}$ and NP rats were compared. The panel of differentially expressed mRNA sequences were then compared with the assembled rat genome to identify the corresponding gene's chromosomal position. With this procedure, two of the three QTL genes were identified in a single experiment. The gene Snca, encoding the synaptic protein $\alpha$-synuclein, was determined by TOGA to be expressed at two-fold higher levels in the hippocampus of $\mathrm{P}$ rat brains compared to the NP rats. Single nucleotide polymorphisms found in the $3^{\prime}$-untranslated region of Snca in the P strain were used to map the gene to the peak of the QTL on chromosome 4. A second gene, glutathione Stransferase 8-8, was identified via TOGA as the QTL gene residing on chromosome $8 .^{66}$ These data illustrate the exceptional promise that expression profiling technologies hold for tracking and identifying genes underlying QTLs.

\section{CONCLUSION}

The development of disease-modifying therapeutics that address the principal causes of neurodegenerative disease is still in its infancy. The current crop of drug targets is based largely upon identified disease gene products and enzymes controlling their metabolism. None of the disease modification strategies developed over the last decade have been proven to be effective in humans. Discovery efforts aimed at target elucidation will need to address these fundamental questions: Why are particular neurons affected by a disease process and not others? What initiates the disease cascade and where is the site of initiation? What is the earliest indicator of pathology? Do resistant neurons use protective mechanisms to maintain cellular homeostasis and how can this knowledge be exploited therapeutically? Answers to these questions will move us closer to beneficial therapies for these devastating illnesses. 


\section{REFERENCES}

1. Winblad, B, Ljunggren, G, Karlsson, G, Wimo, A. What are the costs to society and to individuals regarding diagnostic procedures and care of patients with dementia? Acta Neurol Scand Suppl 168:101-104, 1996.

2. Glenner GG, Wong CW. Alzheimer's disease: initial report of the purification and characterization of a novel cerebrovascular amyloid protein. Biochem Biophys Res Commun 120:885-890, 1984.

3. Hardy J, Selkoe DJ. The amyloid hypothesis of Alzheimer's disease: progress and problems on the road to therapeutics. Science 297:353-356, 2002.

4. Goate A, Chartier-Harlin MC, Mullan M, Brown J, Crawford F, Fidani L, et al. Segregation of a missense mutation in the amyloid precursor protein gene with familial Alzheimer's disease. Nature 349:704-706, 1991.

5. Levy-Lahad E, Wasco W, Poorkaj P, Romano DM, Oshima J, Pettingell WH, et al. Candidate gene for the chromosome $1 \mathrm{fa}-$ milial Alzheimer's disease locus. Science 269:973-977, 1995.

6. Sherrington R, Rogaev EI, Liang Y, Rogaeva EA, Levesque G, Ikeda M, et al. Cloning of a gene bearing missense mutations in early-onset familial Alzheimer's disease. Nature 375:754-760, 1995.

7. Scheuner D, Eckman C, Jensen M, Song X, Citron M, Suzuki N, et al. Secreted amyloid $\beta$-protein similar to that in the senile plaques of Alzheimer's disease is increased in vivo by the presenilin 1 and 2 and APP mutations linked to familial Alzheimer's disease. Nat Med 2:864-870, 1996.

8. Citron M. Strategies for disease modification in Alzheimer's disease. Nat Rev Neurosci 5:677-685, 2004.

9. Hardy J, Gwinn-Hardy K. Genetic classification of primary neurodegenerative disease. Science 282:1075-1079, 1998.

10. Taylor JP, Hardy J, Fischbeck KH. Toxic proteins in neurodegenerative disease. Science 296:1991-1995, 2002.

11. Hutton M, Lendon CL, Rizzu P, Baker M, Froelich S, Houlden H, et al. Association of missense and $5^{\prime}$-splice-site mutations in tau with the inherited dementia FTDP-17. Nature 393:702-705, 1998.

12. Lee VM, Balin BJ, Otvos L Jr, Trojanowski JQ. A68: a major subunit of paired helical filaments and derivatized forms of normal tau. Science 251:675-678, 1991.

13. Prusiner SB. Novel proteinaceous infectious particles cause scrapie. Science 216:136-144, 1982.

14. Spillantini MG, Schmidt ML, Lee VM, Trojanowski JQ, Jakes R, Goedert M. $\alpha$-Synuclein in Lewy bodies. Nature 388:839-840, 1997.

15. Bruijn LI, Houseweart MK, Kato S, Anderson KL, Anderson SD, Ohama E, et al. Aggregation and motor neuron toxicity of an ALS-linked SOD1 mutant independent from wild-type SOD1. Science 281:1851-1854, 1998.

16. Davies SW, Turmaine M, Cozens BA, DiFiglia M, Sharp AH, Ross CA, et al. Formation of neuronal intranuclear inclusions underlies the neurological dysfunction in mice transgenic for the HD mutation. Cell 90:537-548, 1997.

17. DiFiglia M, Sapp E, Chase KO, Davies SW, Bates GP, Vonsattel $\mathrm{JP}$, et al. Aggregation of huntingtin in neuronal intranuclear inclusions and dystrophic neurites in brain. Science 277:19901993, 1997.

18. Dragatsis I, Levine MS, Zeitlin,S. Inactivation of Hdh in the brain and testis results in progressive neurodegeneration and sterility in mice. Nat Genet 26:300-306, 2000.

19. Zuccato C, Ciammola A, Rigamonti D, Leavitt BR, Goffredo D, Conti, L, et al. Loss of huntingtin-mediated BDNF gene transcription in Huntington's disease. Science 293:493-498, 2001.

20. Nitsch RM, Slack BE, Farber SA, Borghesani PR, Schulz JG, $\mathrm{Kim} \mathrm{C}$, et al. Receptor-coupled amyloid precursor protein processing. Ann NY Acad Sci 695:122-127, 1993.

21. Hock C, Maddalena A, Raschig A, Muller-Spahn F, Eschweiler G, Hager K, et al. Treatment with the selective muscarinic $\mathrm{m} 1$ agonist talsaclidine decreases cerebrospinal fluid levels of A $\beta 42$ in patients with Alzheimer's disease. Amyloid 10:1-6, 2003.

22. Vassar R, Bennett BD, Babu-Khan S, Kahn S, Mendiaz EA, Denis $\mathrm{P}$, et al. $\beta$-Secretase cleavage of Alzheimer's amyloid precursor protein by the transmembrane aspartic protease BACE Science 286:735-741, 1999.

23. Dovey HF, John V, Anderson JP, Chen LZ, de Saint Andrieu P, Fang LY, et al. Functional $\gamma$-secretase inhibitors reduce $\beta$-amyloid peptide levels in brain. J Neurochem 76:173-181, 2001.

24. Lanz TA, Himes CS, Pallante G, Adams L, Yamazaki S, Amore $\mathrm{B}$, et al. The $\gamma$-secretase inhibitor $\mathrm{N}$-[N-(3,5-difluorophenacetyl)L-alanyl]-S-phenylglycine t-butyl ester reduces A $\beta$ levels in vivo in plasma and cerebrospinal fluid in young (plaque-free) and aged (plaque-bearing) Tg2576 mice. J Pharmacol Exp Ther 305:864871, 2003.

25. De Strooper B, Annaert W, Cupers P, Saftig P, Craessaerts K, Mumm JS, et al. A presenilin-1-dependent $\gamma$-secretase-like protease mediates release of Notch intracellular domain. Nature 398: 518-522, 1999.

26. Games D, Adams D, Alessandrini R, Barbour R, Berthelette P, Blackwell C, et al. Alzheimer-type neuropathology in transgenic mice overexpressing V717F $\beta$-amyloid precursor protein. Nature 373:523-527, 1995.

27. Luo Y, Bolon B, Kahn S, Bennett BD, Babu-Khan S, Denis P, et al. Mice deficient in BACE1, the Alzheimer's $\beta$-secretase, have normal phenotype and abolished $\beta$-amyloid generation. $\mathrm{Nat} \mathrm{Neu}-$ rosci 4:231-232, 2001.

28. Schenk D, Barbour R, Dunn W, Gordon G, Grajeda H, Guido $\mathrm{T}$, et al. Immunization with amyloid- $\beta$ attenuates Alzheimerdisease-like pathology in the PDAPP mouse. Nature 400:173177, 1999.

29. Iwata N, Mizukami H, Shirotani K, Takaki Y, Muramatsu S, Lu $B$, et al. Presynaptic localization of neprilysin contributes to efficient clearance of amyloid-beta peptide in mouse brain. $\mathrm{J} \mathrm{Neu}$ rosci 24:991-998, 2004.

30. Leissring MA, Farris W, Chang AY, Walsh DM, Wu X, Sun X, et al. Enhanced proteolysis of $\beta$-amyloid in APP transgenic mice prevents plaque formation, secondary pathology, and premature death. Neuron 40:1087-1093, 2003.

31. Gestwicki JE, Crabtree GR, Graef IA. Harnessing chaperones to generate small-molecule inhibitors of amyloid $\beta$ aggregation. Science 306:865-869, 2004.

32. Ross CA. Polyglutamine pathogenesis: emergence of unifying mechanisms for Huntington's disease and related disorders. Neuron 35:819-822, 2002.

33. Chan HY, Warrick JM, Andriola I, Merry D, Bonini NM. Genetic modulation of polyglutamine toxicity by protein conjugation pathways in Drosophila. Hum Mol Genet 11:2895-2904, 2002.

34. Fernandez-Funez P, Nino-Rosales ML, de Gouyon B, She WC, Luchak JM, Martinez P, et al. Identification of genes that modify ataxin-1-induced neurodegeneration. Nature 408:101-106, 2000.

35. Auluck PK, Chan HY, Trojanowski JQ, Lee VM, Bonini NM Chaperone suppression of $\alpha$-synuclein toxicity in a Drosophila model for Parkinson's disease. Science 295:865-868, 2002.

36. Warrick JM, Chan HY, Gray-Board GL, Chai Y, Paulson HL, Bonini NM. Suppression of polyglutamine-mediated neurodegeneration in Drosophila by the molecular chaperone HSP70. Nat Genet 23:425-428, 1999.

37. Katsuno M, Adachi H, Doyu M, Minamiyama M, Sang C, Kobayashi $Y$, et al. Leuprorelin rescues polyglutamine-dependent phenotypes in a transgenic mouse model of spinal and bulbar muscular atrophy. Nat Med 9:768-773, 2003.

38. La Spada AR, Wilson EM, Lubahn DB, Harding AE, Fischbeck $\mathrm{KH}$. Androgen receptor gene mutations in X-linked spinal and bulbar muscular atrophy. Nature 352:77-79, 1991.

39. Schon EA, Manfredi G. Neuronal degeneration and mitochondrial dysfunction. J Clin Invest 111:303-312, 2003.

40. Przedborski S, Jackson-Lewis V. Mechanisms of MPTP toxicity. Mov Disord 13 [Suppl 1]:35-38, 1998.

41. Johns DR, Neufeld MJ, Park RD. An ND-6 mitochondrial DNA mutation associated with Leber hereditary optic neuropathy. Biochem Biophys Res Commun 187:1551-1557, 1992.

42. Jun AS, Brown MD, Wallace, DC. A mitochondrial DNA mutation at nucleotide pair 14459 of the NADH dehydrogenase subunit 
gene associated with maternally inherited Leber hereditary optic neuropathy and dystonia. Proc Natl Acad Sci USA 91:62066210, 1994.

43. Visch HJ, Rutter GA, Koopman WJ, Koenderink JB, Verkaart S, de Groot $\mathrm{T}$, et al. Inhibition of mitochondrial $\mathrm{Na}+-\mathrm{Ca} 2+$ exchange restores agonist-induced ATP production and $\mathrm{Ca} 2+$ handling in human complex I deficiency. J Biol Chem 279:4032840336, 2004.

43a. Shults CW, Flint Beal M, Song D, Fontaine D. Pilot trial of high dosages of coenzyme Q10 in patients with Parkinson's disease. Exp Neurol 188:491-494, 2004.

44. Hart PE, Lodi R, Rajagopalan B, Bradley JL, Crilley JG, Turner $\mathrm{C}$, et al. Antioxidant treatment of patients with Friedreich ataxia: four-year follow-up. Arch Neurol 62:621-626, 2005.

45. Paulson HL, Miller VM. Breaks in coordination: DNA repair in inherited ataxia. Neuron 46:845-848, 2005.

46. Shackelford RE. Pharmacologic manipulation of the ataxia-telangiectasia mutated gene product as an intervention in age-related disease. Med Hypotheses 65:363-369, 2005.

47. Bloom FE, Reilly JF, Redwine JM, Wu CC, Young WG, Morrison JH. Mouse models of human neurodegenerative disorders: requirements for medication development. Arch Neurol 62:185$187,2005$.

48. Nimchinsky EA, Young WG, Yeung G, Shah RA, Gordon JW, Bloom FE, et al. Differential vulnerability of oculomotor, facial, and hypoglossal nuclei in G86R superoxide dismutase transgenic mice. J Comp Neurol 416:112-125, 2000.

49. Wu CC, Chawla F, Games D, Rydel RE, Freedman S, Schenk D, et al. Selective vulnerability of dentate granule cells prior to amyloid deposition in PDAPP mice: digital morphometric analyses. Proc Natl Acad Sci USA 101:7141-7146, 2004.

50. Reilly JF, Games D, Rydel RE, Freedman S, Schenk D, Young WG, et al. Amyloid deposition in the hippocampus and entorhinal cortex: quantitative analysis of a transgenic mouse model. Proc Natl Acad Sci USA 100:4837-4842, 2003.

51. Ginsberg SD, Hemby SE, Lee VM, Eberwine JH, Trojanowski JQ. Expression profile of transcripts in Alzheimer's disease tangle-bearing CA1 neurons. Ann Neurol 48:77-87, 2000.

52. Sutcliffe JG. Open-system approaches to gene expression in the CNS. J Neurosci 21:8306-8309, 2001.

53. Sutcliffe JG, Foye PE, Erlander MG, Hilbush BS, Bodzin LJ, Durham JT, et al. TOGA: an automated parsing technology for analyzing expression of nearly all genes. Proc Natl Acad Sci USA 97:1976-1981, 2000.

54. Bales KR, Verina T, Dodel RC, Du Y, Altstiel L, Bender M, et al. Lack of apolipoprotein $\mathrm{E}$ dramatically reduces amyloid $\beta$-peptide deposition. Nat Genet 17:263-264, 1997.

55. Corder EH, Saunders AM, Strittmatter WJ, Schmechel DE, Gaskell PC, Small GW, et al. Gene dose of apolipoprotein E type
4 allele and the risk of Alzheimer's disease in late onset families. Science 261:921-923, 1993.

56. Lambrechts D, Storkebaum E, Morimoto M, Del-Favero J, Desmet F, Marklund SL, et al. VEGF is a modifier of amyotrophic lateral sclerosis in mice and humans and protects motoneurons against ischemic death. Nat Genet 34:383-394, 2003.

57. Li JL, Hayden MR, Almqvist EW, Brinkman RR, Durr A, Dode C, et al. A genome scan for modifiers of age at onset in Huntington disease: the HD MAPS study. Am J Hum Genet 73:682-687, 2003.

58. Parton MJ, Broom W, Andersen PM, Al-Chalabi A, Nigel Leigh P, Powell JF, et al. D90A-SOD1 mediated amyotrophic lateral sclerosis: a single founder for all cases with evidence for a Cisacting disease modifier in the recessive haplotype. Hum Mutat 20:473, 2002.

59. van der Walt JM, Noureddine MA, Kittappa R, Hauser MA, Scott WK, McKay R, et al. Fibroblast growth factor 20 polymorphisms and haplotypes strongly influence risk of Parkinson disease. Am J Hum Genet 74:1121-1127, 2004.

60. Li YJ, Scott WK, Hedges DJ, Zhang F, Gaskell PC, Nance MA, et al. Age at onset in two common neurodegenerative diseases is genetically controlled. Am J Hum Genet 70:985-993, 2002.

61. Eaves IA, Wicker LS, Ghandour G, Lyons PA, Peterson LB, Todd JA, et al. Combining mouse congenic strains and microarray gene expression analyses to study a complex trait: the NOD model of type 1 diabetes. Genome Res 12:232-243, 2002.

62. Li YJ, Oliveira SA, Xu P, Martin ER, Stenger JE, Scherzer CR, et al. Glutathione S-transferase omega-1 modifies age-at-onset of Alzheimer disease and Parkinson disease. Hum Mol Genet 12: 3259-3267, 2003.

63. Bice P, Foroud T, Bo R, Castelluccio P, Lumeng L, Li TK, et al. Genomic screen for QTLs underlying alcohol consumption in the $\mathrm{P}$ and NP rat lines. Mamm Genome 9:949-955, 1998.

64. Carr LG, Foroud T, Bice P, Gobbett T, Ivashina J, Edenberg H, et al. A quantitative trait locus for alcohol consumption in selectively bred rat lines. Alcohol Clin Exp Res 22:884-887, 1998.

65. Liang T, Spence J, Liu L, Strother WN, Chang HW, Ellison JA, et al. $\alpha$-Synuclein maps to a quantitative trait locus for alcohol preference and is differentially expressed in alcohol-preferring and -nonpreferring rats. Proc Natl Acad Sci USA 100:46904695, 2003.

66. Liang T, Habegger K, Spence JP, Foroud T, Ellison JA, Lumeng $\mathrm{L}$, et al. Glutathione S-transferase 8-8 expression is lower in alcohol-preferring than in alcohol-nonpreferring rats. Alcohol Clin Exp Res 28:1622-1628, 2004.

67. Chen YZ, Bennett CL, Huynh HM, Blair IP, Puls I, Irobi J, et al. DNA/RNA helicase gene mutations in a form of juvenile amyotrophic lateral sclerosis (ALS4). Am J Hum Genet 74:1128-1135, 2004. 